DOI: $10.22616 /$ j.balticsurveying.2018.003

\title{
POTENTIAL OF BROWNFIELDS AS DEVELOPING TERRITORIES IN BRATISLAVA
}

\author{
Julius Golej, Miroslav Panik \\ Slovak University of Technology in Bratislava, Slovakia
}

\begin{abstract}
The issue of brownfields and their analysis in Slovakia have not been given such emphasis over the last decade as in the neighbouring EU countries, such as in Austria or in the Czech Republic. The situation is completely different in Bratislava and also in the rest of Slovakia and the development of this type of area is almost unrealized. A frequent argument is problematic ownership relationships to the unused, degraded land. However, the real problem is the higher financial costs associated with brownfields regeneration. Despite this fact, brownfields can be considered as an area with relatively large development potential within the urbanized area and one form of hidden reserves of both, local and national economy. Among the indisputable benefits of using brownfields, we can include reduction of the extensive land use of agricultural land for rural area. In the long run, Bratislava is preparing a search study of neglected and unused land within the capital. It is due to be completed in the course of 2018, and will be an important basis for a new territorial plan and the development of Bratislava. In the following article, we analyse brownfield land in Bratislava. The already realized brownfield projects are also mentioned, while we are trying to point out their main advantages and disadvantages.
\end{abstract}

Key words: brownfield, Bratislava, property development, greenfield.

\section{Introduction}

Generally, historical centres and major transport hubs are considered to be the most attractive places for construction, especially in large cities. Historic centres are very interesting for housing, hotel business, services and lucrative office space, especially to simple accessibility by both public and private transport and prestige addresses for owners and also for tenants. Their attractiveness is also enhanced by quality architecture, plenty of greenery, shops and services. Of course, on the other hand, construction options are quite limited in these locations.

A critical problem of the urban development in Slovakia is appearance of the underused sites after the suppression of the industrial activities (Špirková, Zúbková, 2017). Particularly in these localities, Bratislava has great potential. It is a naturally growing economic and cultural centre that requires new construction and innovative concepts of development.

Brownfields as areas that are not used in accordance with the original function represent a significant land reserve for the future development of Bratislava. Around $40 \%$ of former industrial sites remained unused by brownfields after the building boom in Bratislava, the capital of the Slovak Republic (Stanilov, 2007). Unlike Vienna, where brownfields are the only areas for development in the densely populated area of the capital of Austria. As examples we can mention the airport in Aspern (Fig. 1), where a new quarter is built predominantly with the function of housing or in the past refurbished gas tanks Gasometer (Fig. 2). The city's leadership approaches the shaping of the future of these territories through a participatory policy. The development of a new block or neighbourhood is open to the professional public as well to all actors in the area.

The non-use of brownfields is often conditioned by lack of or insufficient inventory and cataloguing of existing problems and values of the territory, unclear ownership and lack of concept of individual public sector activities (Finka, 2011).

Bratislava is the capital and fulfils the function of the top administrative and political centre of the Slovak Republic. It is administratively divided into 5 urban districts, which are further divided into urban areas and local areas, some of which are further divided into local sections. There are 17 urban areas and 48 localities in Bratislava. Urban areas are managed by local authorities. The district offices provide the state administration in the city and the regional office ensures the performance of the state administration at the level of the region. The city is incorporated into the Bratislava Region, which consists of 3 outer city districts and 5 inner city districts. Bratislava is an independent urban whole 
with an area of $367.6 \mathrm{~km} 2$ with a population of 425,000 inhabitants and a wide regional background of 600,000 inhabitants (Master plan of the city of Bratislava, 2007).

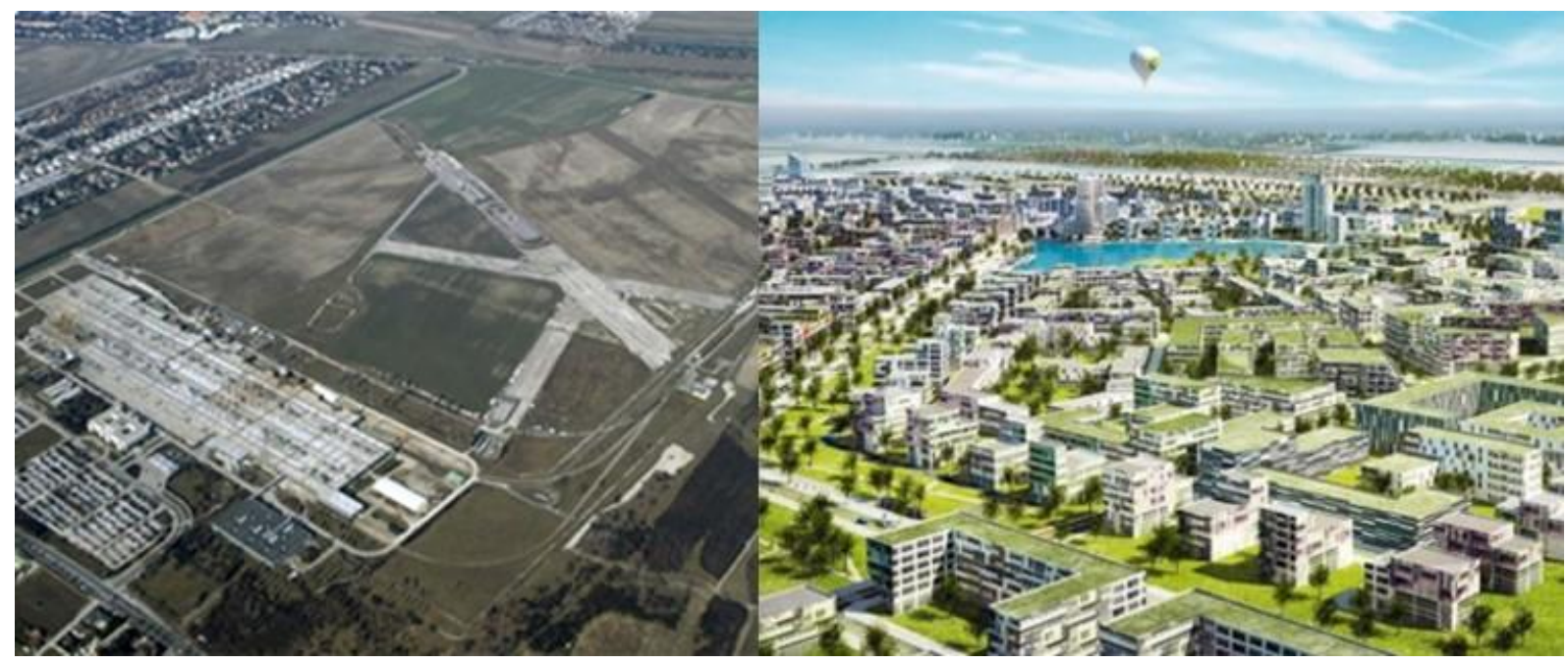

Fig. 1. Aspern, district of Vienna - on the left: the original area of the airport; on the right: a new residential area.

Sources: http://fm4v3.orf.at/stories/1663777/index.html; http://www.igzt.at/index.php?seitenId=11\&projekteId=115

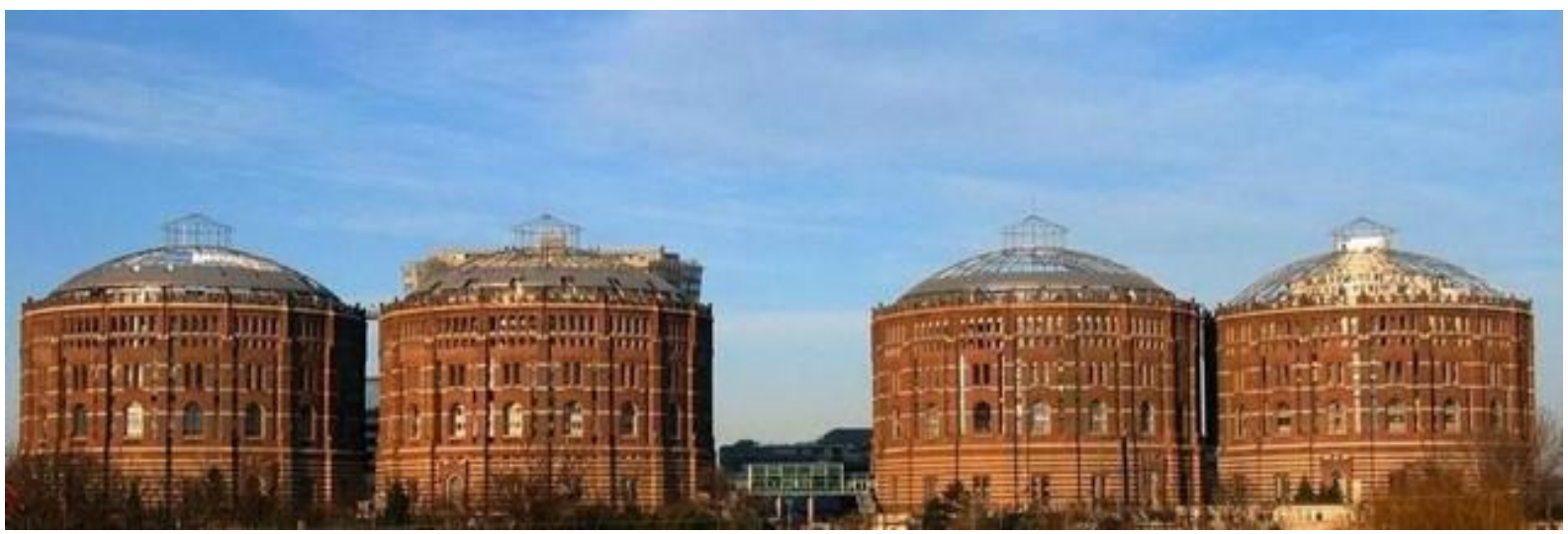

Fig. 2. Gasometer - a city within a city

Source: https://en.wikipedia.org/wiki/Gasometer,_Vienna\#/media/File:Gasometer-hyblerpark2001.jpg

Development in the form of new construction is currently evident in almost every part of Bratislava. It is a positive fact that in many cases there is thickening within the city's intravilan, which making the space more efficient. On the other hand, the free landscape is also being urbanized. Future developments should go more strongly into the city, especially to the brownfields. In this case, environmental burdens have to be removed, one of the biggest problems of Bratislava. Investments in brownfield regeneration are often associated with high risks. Developers without accurate costing and risk factors cannot assess the real profitability of the regeneration project. This is why they often prefer construction on greenfield areas (Petríková, 2011). In addition, brownfield projects require not only an experienced developer, but also a financially strong company. The economically demanding restorations lay in high costs for decontamination, including demolition work. Other hindrances include financing and organisational obstacles contained in the tax system and its application, difficulties in obtaining loans, the lack of quality developers and investment advisors, complicated procedures with respect to obtaining all the construction permits, etc. (Špirková, Zúbková, 2017). 


\section{Main goal of the article}

It is to point out the current problems of the city of Bratislava resulting from the current events caused by many development activities on brownfield areas, located in the very center of the city. The main and often the only benefit of these projects is that they eliminate the problem of abandoned territories. However, these activities often prove that the city has no elaborated concept of its development and so its future is basically decided by the developer with their projects. New projects are made without consideration, only for the purpose of achieving the highest profit, as the current situation on the real estate market in Bratislava is more than favorable.

\section{Methodology of research and materials}

Neither Slovakia nor the city of Bratislava has currently mapped their abandoned and unused territories. Only during May 2018, initiative emerged from the city and mapping of the brownfield area in Bratislava was launched. The study has consistently identified 390 such locations, including not only former production facilities, but also premises after civic amenities, transport facilities, army facilities or neglected and unused public spaces.

The Municipality of Bratislava focused on large unused areas through a questionnaire forms. The aim is to map the abandoned territories (where they are located and what their basic characteristics are) and to find out who owns the land. In the questionnaire, the municipality defines a brownfield as a space / site affected by a construction that has lost its original use and is completely abandoned or only partially used (approx. 30\% of utilization). These areas should have at least $5000 \mathrm{~m} 2$ (0.5 ha) and loss of their full function lasts more than 2 years.

The questionnaire is intended as part of the preparatory work of urban studies - Brownfields in the city Bratislava. Its elaboration will be an important basis for the new Master plan and for the future development of Bratislava with the expected date of completion in 2019.

Further involvement of the public in addressing the brownfields issue in Bratislava has been organized by the Initiative "Bratislava City - Where I Want to Live" in 2016. Through a questionnaire forms about 1,200 inhabitants were interviewed about the most abandoned locations in the city. These should be located in the wider city centre and occupy a larger area. Based on a consultation with several experts, the order of brownfields was compiled that met these parameters and the public has drawn up a list of the most problematic areas in Bratislava.

Below, we present the 5 most problematic areas perceived by the public. Contrary to this survey, we also show two examples of the most successful brownfield regeneration projects in Bratislava, again from the point of view of the public as well as the experts.

\section{Discussions and results}

The most negative perceived brownfield areas in Bratislava

\section{Former railway station „Filialka“ at Trnavske myto}

Bratislava Filialka Railway Station (Fig. 3) stands near the place where the first railway station in Slovakia - Pressburg Blumenthal was. The Filialka was part of it. The decision to omit the station from the Trnava - Bratislava electrification program after 1980 caused the beginning of its decline. Passenger traffic here was cancelled in 1985, and the station was subsequently removed from the list of stations. Several projects have been planned here in the past, but they have never been implemented. At present, on one part of the huge area of this territory, the residential development project "Urban Residence" is completed. 


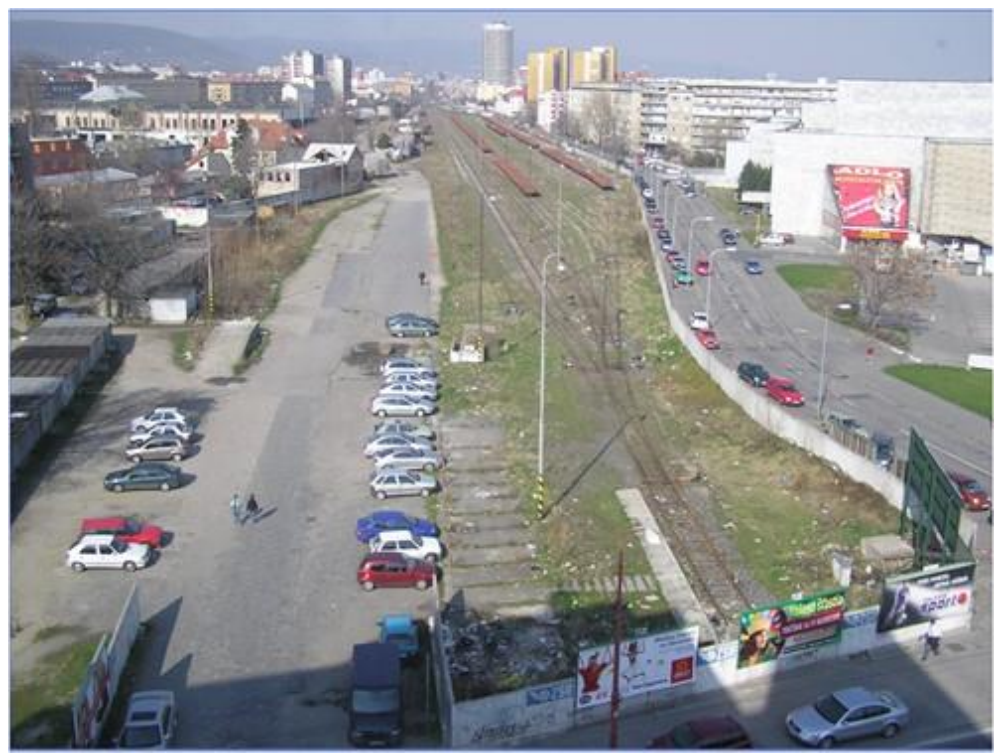

Fig. 3. Former railway station Filialka

Source: http://www.hrapko.sk/www-eshop-rychlo-sk-hrapko/e-news/0/2/120

\section{The former swimming pool Lido}

The Lido swimming pool was established in 1924. It was one of the largest and most modern beach resorts in the former Czechoslovakia. It was located on the Petrzalka bank of the Danube (Fig. 4) in the area between the Old Bridge and the new Apollo Bridge. It worked until the early 80s of the 20th century. In the 1990s, plans were created for its renewal where it had to be part of a larger recreation area, but they have not been implemented. A large area of neglected territory in close proximity to free-time functions (park and shopping centre) has been unnoticed for almost 30 years, which has also caused its partial afforestation.

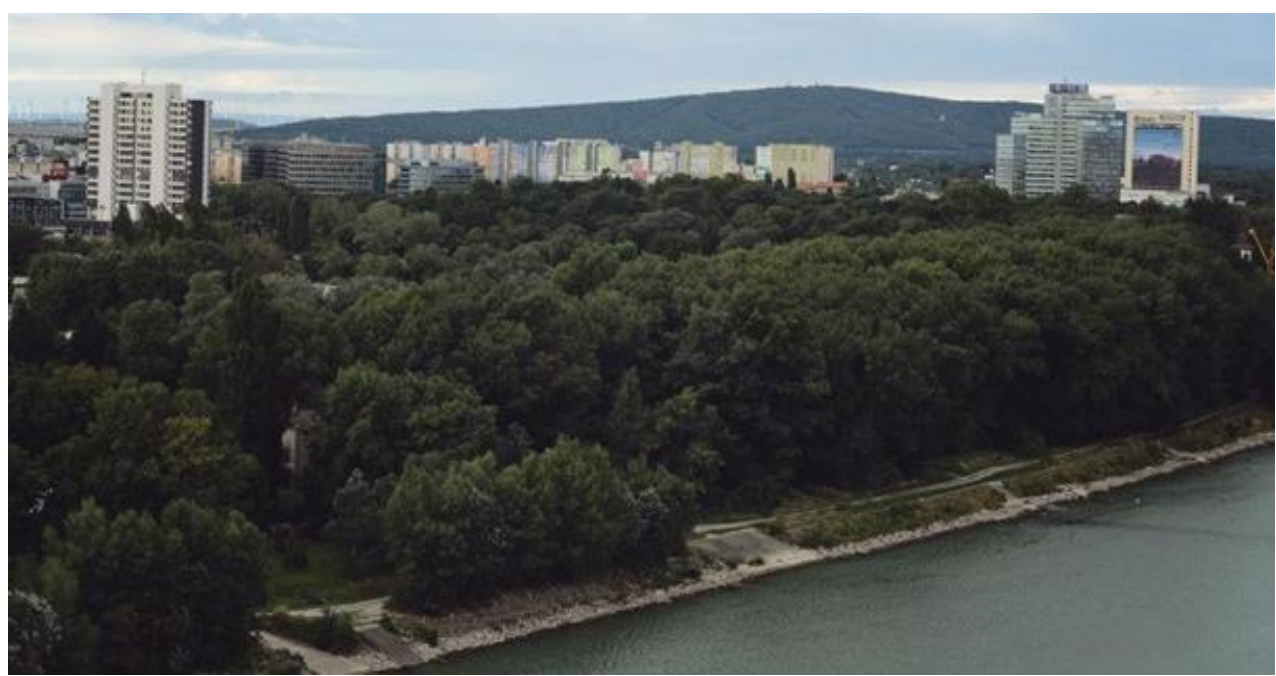

Fig. 4. The former swimming pool Lido

Source: https://www.etrend.sk/gallery/article/6-najcennejsich-rozvojovych-lokalitbratislavy.html?photo=3

\section{Heating plant on Landerer's Street}

The building of heating plant was started in 1941 and completed it in 1944. The heating plant (Fig. 5) was part of Bratislava's industrial centre. It is a work of Dusan Jurkovic, who is considered the founder of the Slovak modern architecture. The heating plant has been included in the list of cultural monuments. At present, it has become part of a multifunctional complex with the city park, which is growing at this point. This is the last of the formerly preserved part of the former industrial zone. 


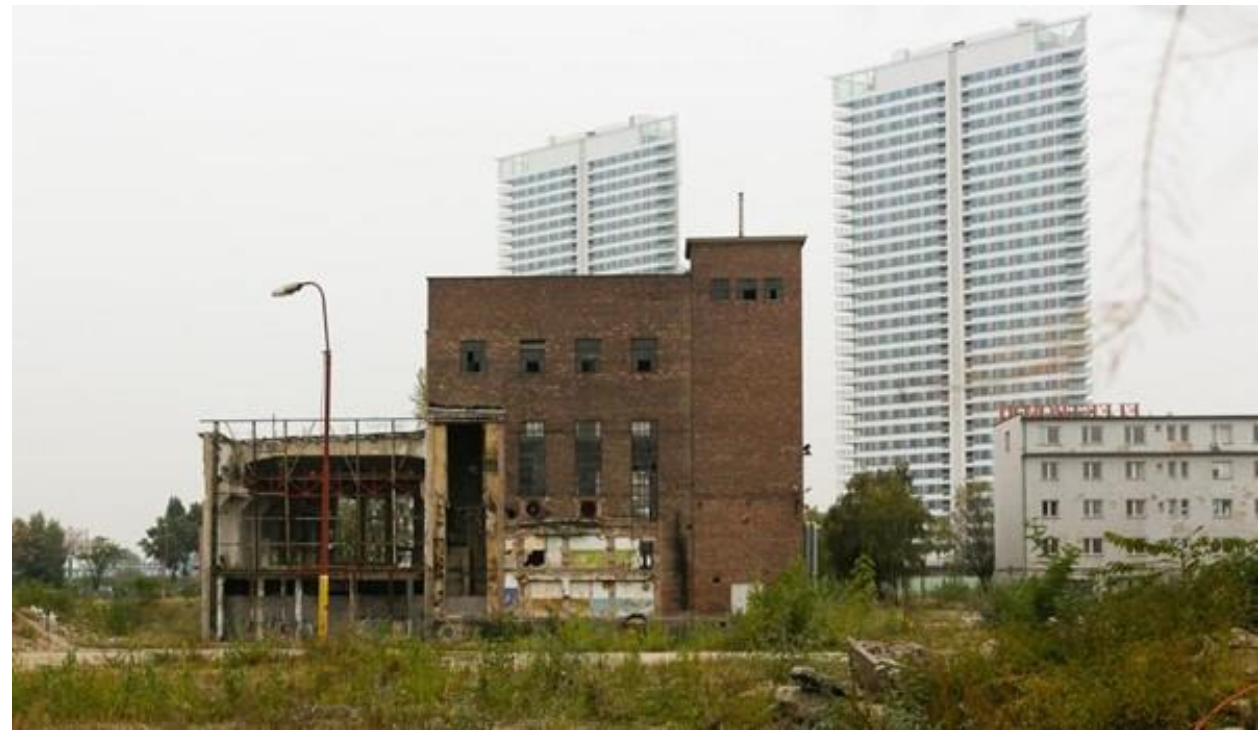

Fig. 5. The Jurkovic's heating plant

Source: https://www.etrend.sk/gallery/article/culenova-od-zahy-hadid-ma-novy-nazov-skypark.html?photo $=10$

\section{The Winter port}

The Winter port on the Danube (Fig. 6) was built at the end of the 19th century. It was once one of the largest ports in Central Europe, with more than 20 smaller factories in the 1970s. The current use of transhipment and wintering of ships is slowly falling. The port is today one of the last remnants of the oldest industrial zone in Bratislava. There are dozens of boats, cranes, but also a gas station, the Old House of the Ship-owners (National Cultural Monument), shipping pools or ship workshop from 40's with bridge crane and ship lift.

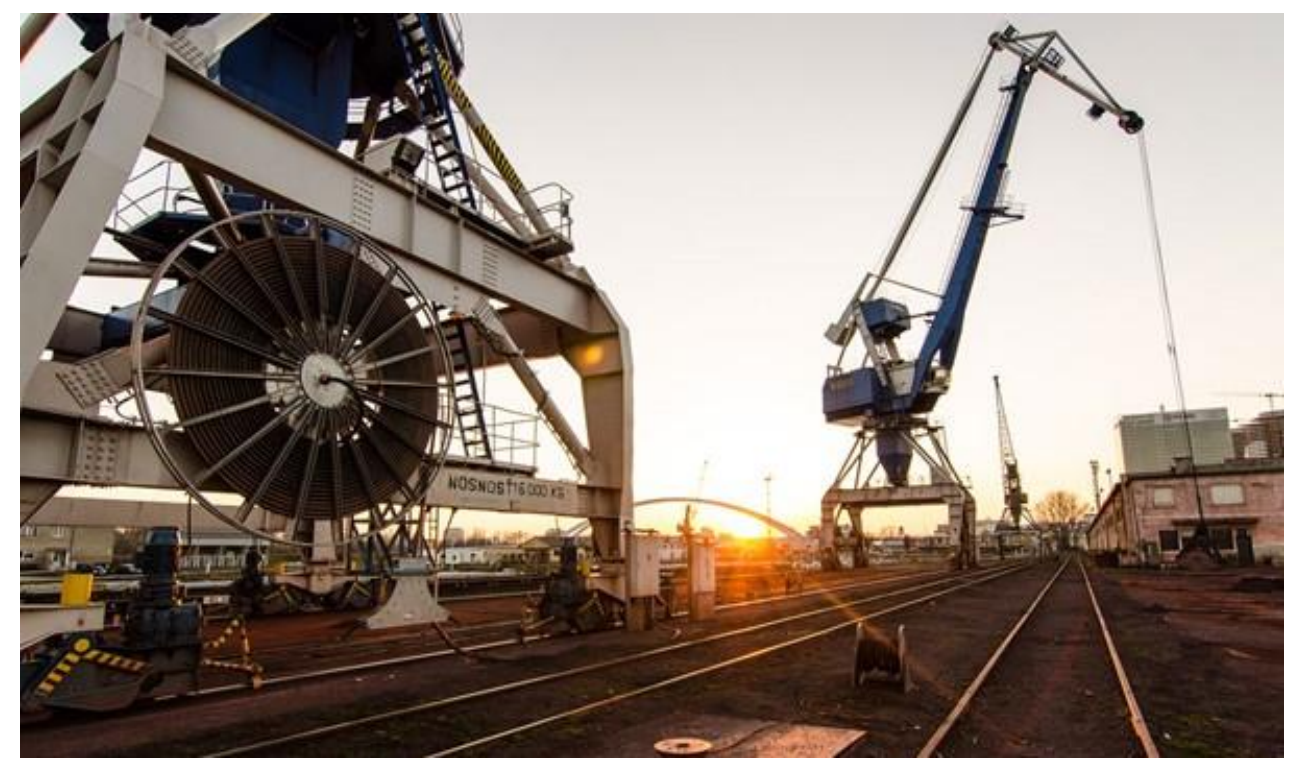

Fig. 6. The Winter port on the Danube

Source: http://ciernediery.sk/zimny-pristav-v-bratislave/

\section{Jaskovy rad}

It represents a long-term (about 40 years) unspoilt area in close proximity to the centre and the main station of the capital. This is the main link between Prazska Street and Pionierska Street with never realized plans for tunnel construction or extension of railway lines. The territory (Fig. 7) has been framed by old fences and various waste on it for many years. 


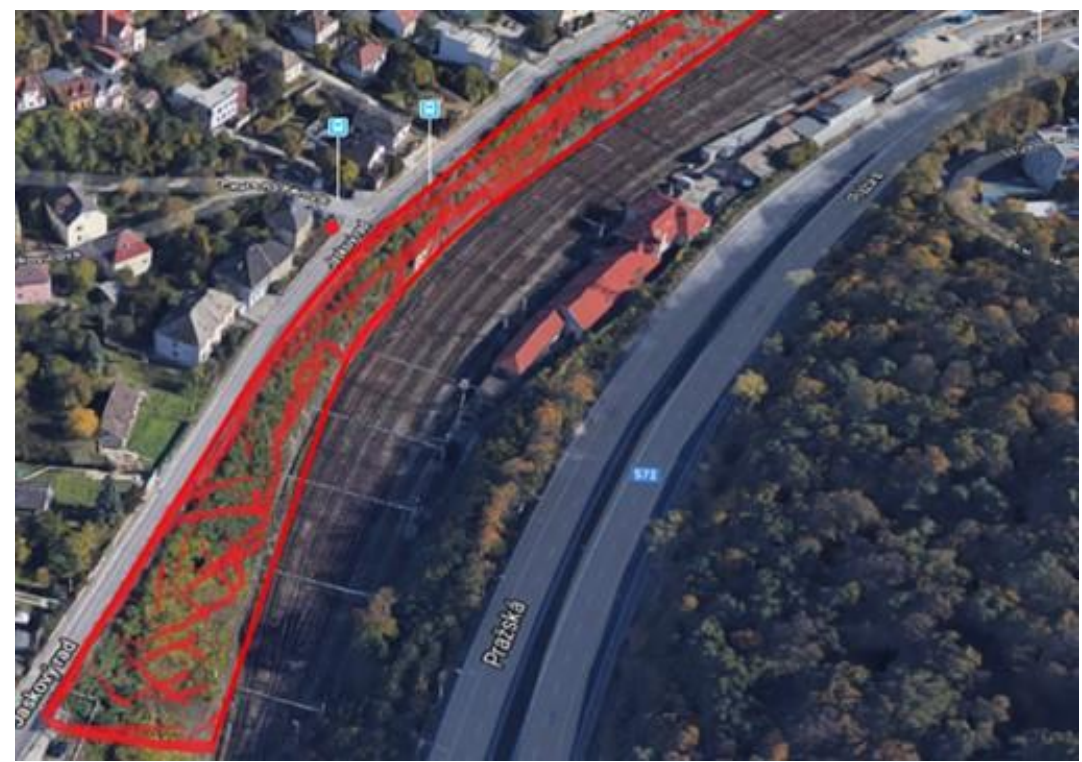

Fig. 7. Abandoned territory of Jaskovy rad Source: Google maps and authors

\section{Successful brownfield land regeneration projects in Bratislava}

Despite the fact that the city of Bratislava has not undergone an inventory of degraded and abandoned areas in recent years, we can mention a few examples of successful regeneration of brownfields in the city.

\section{Project Eurovea}

It is a development project built on the territory of the former brownfield, namely the former refinery Apollo (Figure 8), which was destroyed by the bombing of allied troops at the end of the Second World War. The territory after the bombing was heavily contaminated with oil and various petroleum products, so it remained unused and abandoned for over half a century. Until 2006, when it was reconstructed. This area lies on the right bank of the Danube River, near the historical centre of Bratislava. The 230,000-square-meter project includes offices, apartments, and the largest underground car park in Bratislava for 1,700 cars. Nearly two-thirds of Eurovea's area is greenery and public spaces, including the Danube promenade. The Eurovea complex also included the incorporation of a new building of the Slovak National Theatre into the project itself. Another specific feature of the Eurovea project was the implementation of effective flood protection measures for over EUR 1 million. The system forms an underground reinforced concrete wall for protection against thousands of years of water, including a mobile lamella construction to increase the protective barrier by an additional $50 \mathrm{~cm}$. Currently, the construction of the second part of the Eurovea - "Eurovea II" project is planned to extend the entire complex by another 116 thousand square meters, bringing additional features such as residential, retail and administration. By combining both parts of the projects (Figure 9) there is a tendency for the creation of a new full-fledged city district.

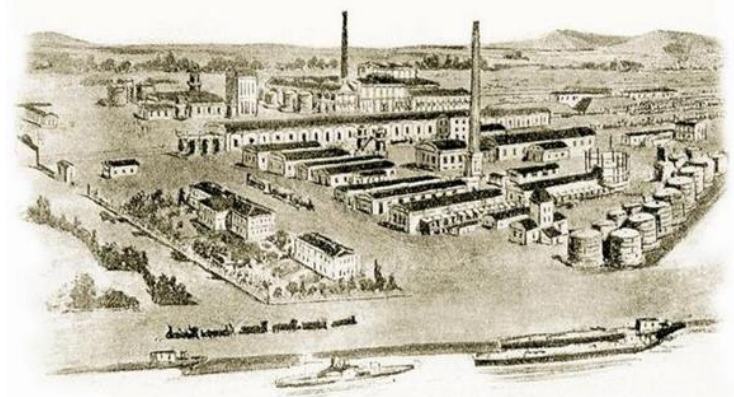

Fig. 8. Apollo refinery old painting

Source: http://energia.sk/fotogaleria/ropa-a-ropne-paliva/v-obrazoch-pribeh-rafinerieapollo/10148/ 


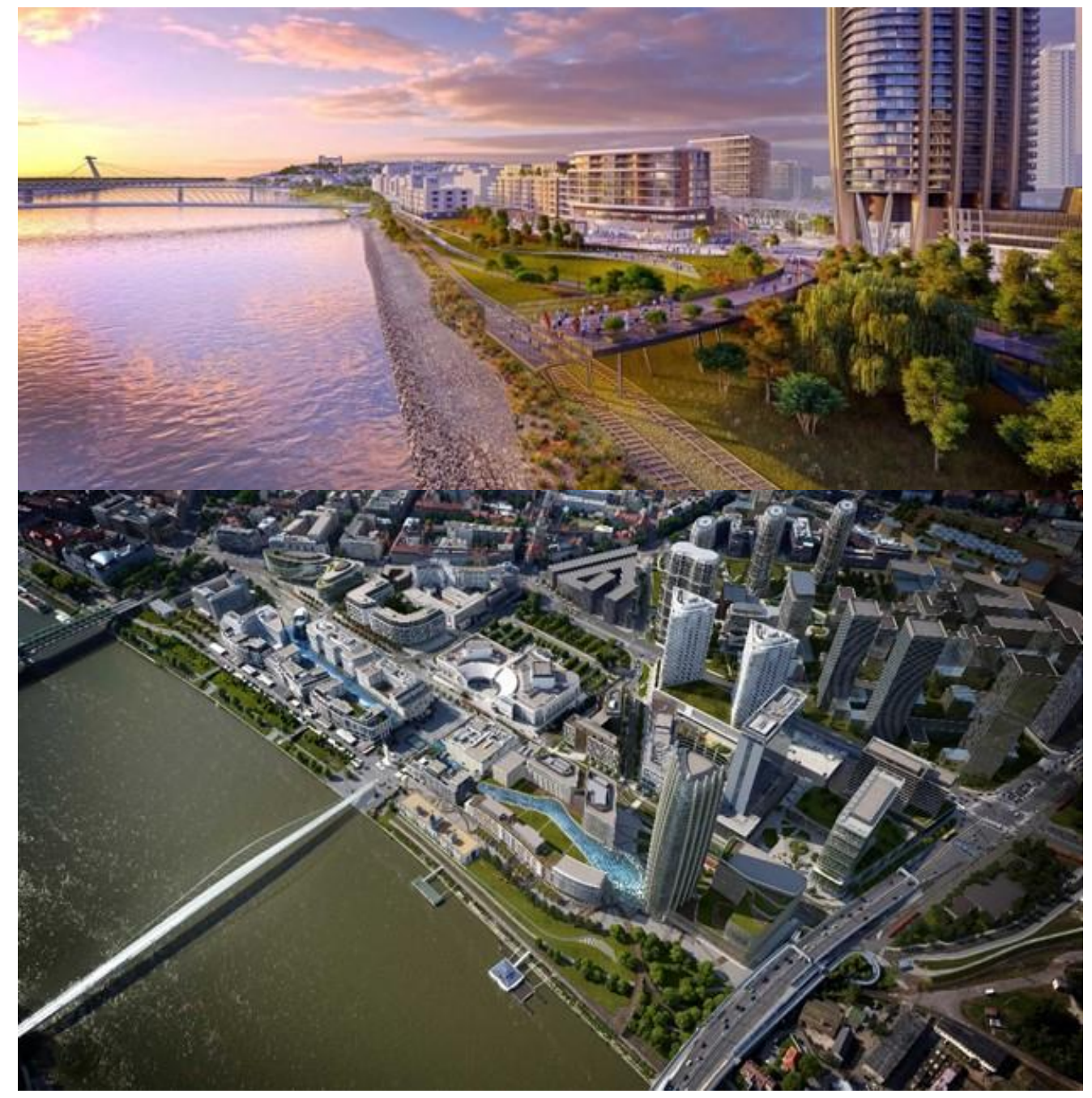

Fig. 9. The Eurovea and Eurovea II projects as a new city district Source: http://www.jtre.sk/projekty/eurovea-II

\section{Mlynske Nivy Bus Station}

The original bus station Mlynske Nivy (Fig. 10) was the largest bus station in Bratislava, the place of arrival and departure of inter-city buses within Slovakia and abroad. It was conveniently located for long distance transportation in the wider city centre. Construction began in 1979 and finished in 1983. In 2017, the developer began with its complete redevelopment, by setting up a replacement bus station in the vicinity. In addition to a station located in the former industrial zone, construction is being carried out on almost all of the surrounding land. Including regeneration of one of the main traffic arteries of Bratislava and its transformation into a spacious city boulevard. It is a redevelopment of the entire former industrial zone into a new, modern city district that, besides the new station (Fig. 11), will contain a residential, administrative and retail function. In the former industrial zone, there was a cable factory Kablo Bratislava (Fig. 12). Founded in 1895, the factory was engaged in the production of electro-technical materials, especially power cables and wires. All factory buildings were completely demolished between 2007 and 2008. The New Bus Station project will be completed in 2020 and the entire zone New Nivy in 2023. 


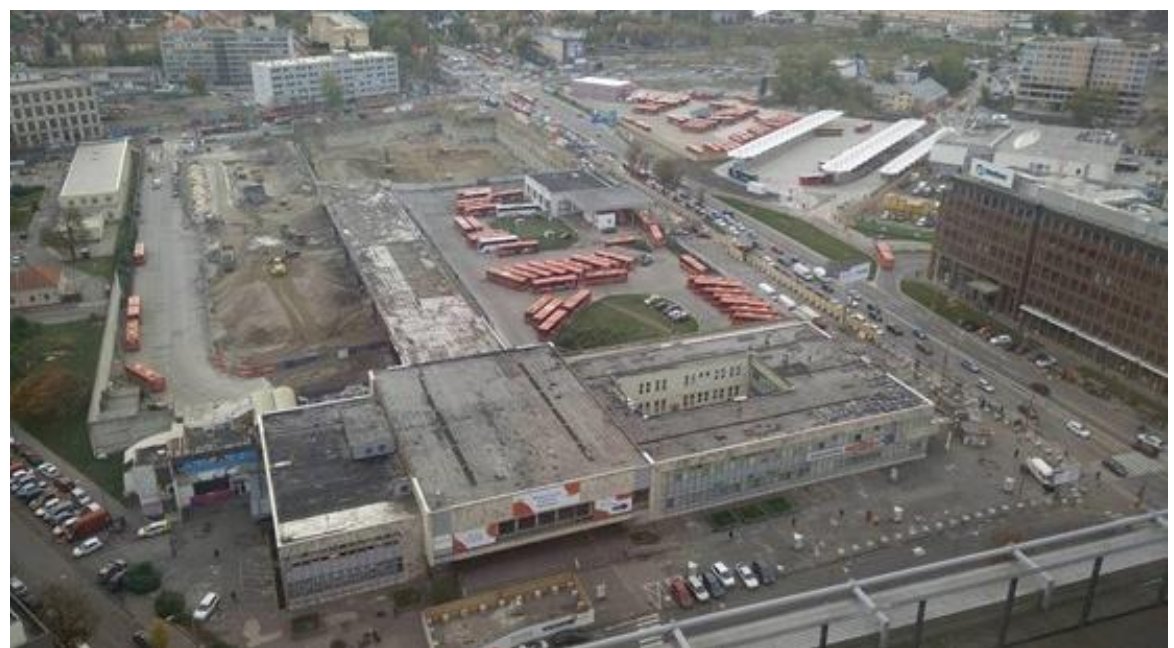

Fig. 10. The original bus station Mlynske Nivy

Source: https://www.skyscrapercity.com/showthread.php?p=143167724

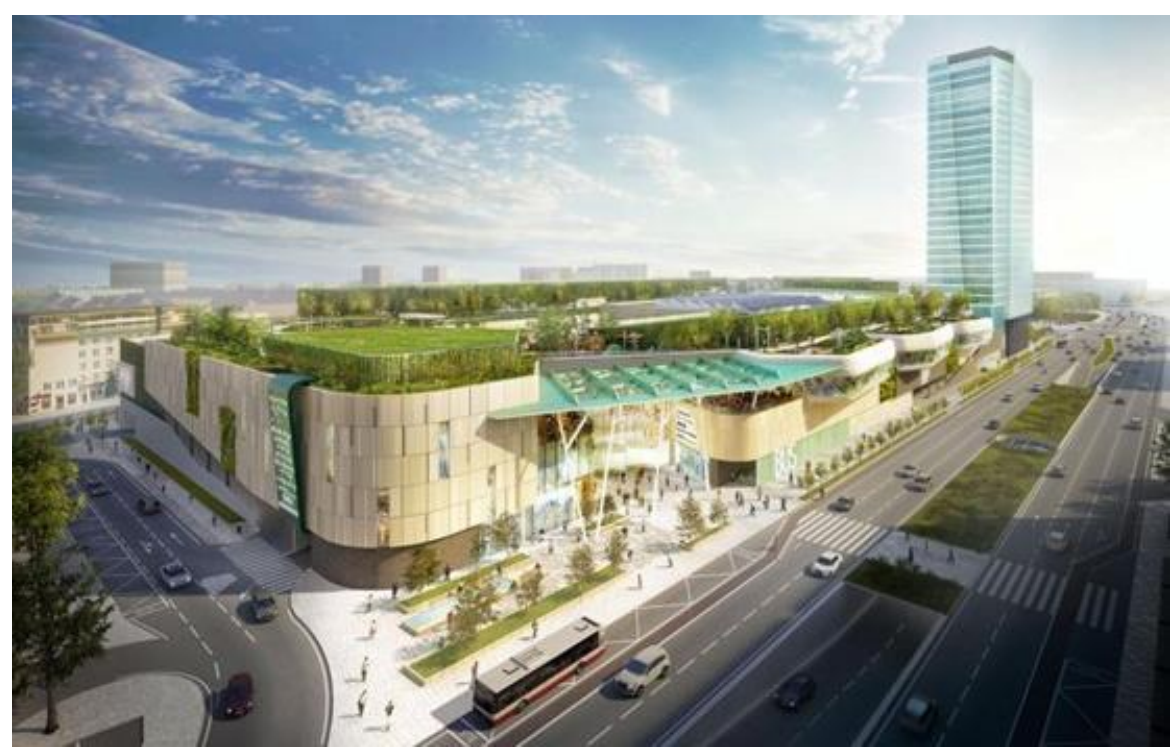

Fig. 11. New bus station Nivy

Source: https://www.etrend.sk/gallery/article/hb-reavis-zacne-rekonstruovat-mlynske-nivy-v-majiulicu-uplne-neuzavrie.html?photo=7

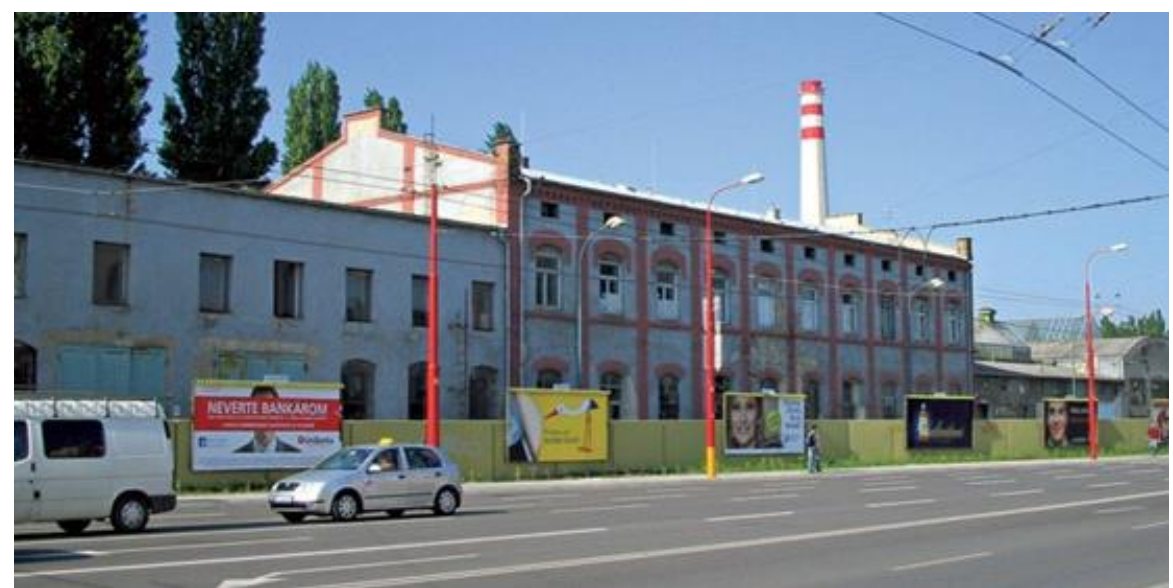

Fig. 12. Kablo Bratislava Factory

Source: https://www.asb.sk/fotogalerie/architektura/kablovka-vbratislave-fotoalbum/kablovkavbratislave-1 


\section{Conclusions and proposals}

The post-industrial heritage of the urban environment of the developed countries are brownfields of local, settlement and higher importance. Extensive premises, land and buildings of a productive nature in the lucrative inner city are burdens for the entire city and require special attention in land use planning and its regulation. It should be added that the development of brownfields also entails a variety of risks, particularly as a result of increased project construction costs. Therefore, developers often prefer construction on greenfields, which leads to a relatively dynamic occupation of agricultural land in the vicinity of Bratislava. Over the last few years, we are witnesses of an increasing land grabbing of vineyards at the expense of new construction.

The initiative for the transformation of brownfields would have to come out of the land owners as well. The natural motive is the effort to redevelop their own land. The situation is aggravated by unclear property and legal relations and, in many cases, also environmental burdens. Brownfields often negatively affect the neighbouring zones. They often discourage investors and reduce their business activities in the affected areas. Further impacts may be job cuts, a reduction in the value of neighbouring properties, reduced production rates and lower living standards. Brownfields may cause also lower environmental standards, can lead to the loss of a capable, young population and create social and environmental inequality.

Main proposals of authors are:

\section{1. to develop an invetarisation of the brownfield territories}

Slovakia, including Bratislava, still has no inventory of brownfields in its territory. Although currently the first steps of mapping these areas begun, the result of the ongoing situation is the absence of significant amounts of potential development areas of the city that are not reflected in the current land use plan of Bratislava.

\section{2. clearly define strategic development goals of the city of Bratislava}

In addition, Bratislava does not have clearly defined strategic development goals in the long term. This results in a wild, non-conceptual construction activities where private developers have the main word. They realize their projects on the basis of their visions and ideas, without their activity being directed by the local government, as it does not have the mentioned strategic plans and objectives.

\section{3. to establish a functional fee institute for development}

New projects often have an undesirable impact on the traffic situation in the city, as communications and their features are under-estimated. Catastrophic is also the traffic-capacity assessment of large investment plans and unsustainable parking standards. These together cause that Bratislava is cluttered with cars, for which there is no place anymore and which, under the current system, only causes other serious problems for the city. Investments to infrastructure from the most new projects are very low and inadequate.

\section{4. to establish a planning and conceptual organization unit}

Bratislava and its government are lagging behind standards that are becoming common not only in cities on the west or north of us. These include a lack of parking policy, the absence of architectural competitions, the absence of a manual for creating public spaces and missing planning and conceptual organization unit. The qualitative contrast between the private and the public sector must be overcome as soon as possible, and this will be the biggest challenge for the upcoming period.

\section{Acknowledgement}

This paper is supported and funded from the VEGA grant no. 1/0604/18, entitled "Economic Aspects of Sustainable Construction within Intelligent Urban Structures" and KEGA grant no. 019STU$4 / 2018$, entitled "The process of integrating mentoring and coaching into teaching at technical universities".

\section{References}

1. Spirkova, D., Zubkova, M. (2017) Importance of Development Companies in Redevelopment Process. 29th International-Business-Information-Management-Association Conference. Vienna, Austria. pp. 4245-4252. ISBN:978-0-9860419-7-6. WOS:000410252702168

2. Stanilov, K. (2007) The post socialist city. Urban form and Space Transformations in Central and Eastern Europe after Socialism. Springer, GeoJournal Library. 92. 
3. Finka, M. (2011) Brownfieldy - aktuálny problém priestorového rozvoja (in Slovak language). (Brownfields - a current issue of spatial development). In: Urbanita. 2011, vol. 3/2011, p. 6-9.

4. Master plan of the city of Bratislava (2007) Municipality of the capital city of SR - Bratislava. (in Slovak language). Available on: https://bratislava.sk/sk/uzemny-plan

5. Petríková, D (2011) Klasifikácia a hodnotenie možností regenerácie brownfieldov (in Slovak language). (Classification and evaluation of brownfields regeneration). In: Urbanita. Bratislava p. 10-13, ISSN 01395912.

\section{Information about authors}

Julius Golej, MSc., PhD., lecturer and researcher at the Institute of Management of Slovak University of Technology in Bratislava (STU in BA). Vazovova street no. 5, Bratislava, 812 43, Slovakia, e-mail: julius.golej@stuba.sk. His research is focused on real estate market, property development, land management and related technical-economic issues.

Miroslav Panik, MSc., PhD., lecturer and researcher at the Institute of Management of Slovak University of Technology in Bratislava (STU in BA). Vazovova street no. 5, Bratislava, 812 43, Slovakia, e-mail: mirosla_panik@stuba.sk. His research is focused on issues of real estate, especially on modeling of property prices. 